\title{
PENINGKATAN PRESTASI BELAJAR IPA FISIKA DENGAN MENERAPKAN PEMBELAJARAN TUNTAS (MASTERY LEARNING) KELAS XI-TKJ SMK NEGERI 1 NARMADA KABUPATEN LOMBOK BARAT TAHUN PELAJARAN 2019-2020
}

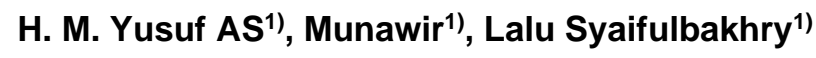 \\ 1)SMKN 1 Narmada, Kabupaten Lombok Barat, NTB, Indonesia \\ Corresponding author: H. M. Yusuf AS \\ E-mail : hajiyusuf64@gmail.com
}

Diterima 04 Oktober 2021, Direvisi 20 Oktober 2021, Disetujui 20 Oktober 2021

\begin{abstract}
ABSTRAK
Prestasi belajar adalah hasil atau akibat dari kegiatan belajar.Untuk mengetahui tentang prestasi belajar perlu dijelaskan tentang hakekat belajar.Belajar merupakan suatu proses yang dilakukan seseorang untuk memperoleh suatu perubahan tingkah laku yang baru secara keseluruhan,sebagai hasil pengalaman ( Slameto,1991).Dimana perubahan itu bersifat kontinyu dan fungsional,terjadi secara sadar,bersifat positif dan aktif,bukan bersifat sementara,bertujuan atau terarah,dan mencakup seluruh aspek tingkah laku yang selanjutnya dinamakan prestasi belajar. Prestasi belajar dapatdikatakan membekas atau konstan, jika perubahan yang terjadi akibatproses belajar tahan lama dan tidak terhapus begitu saja.Proses pembelajaran khususnya IPA Fisika akan lebih efektifdan bermakna apabila siswa berpartisi aktif, dengan cara tidakmenunjukkan sikap pasif di dalam kelas maupun di luar kelas. Tetapisampai saat ini masih banyak terdengar keluhan bahwa mata pelajaranIPA Fisika membosankan, tidak menarik, memusingkan yang cenderungmembuat siswa menjadi kurang merespon saat pelajaran berlangsung,bahkan ada siswa yang tidak masuk sekolah dikarenakan ada matapelajaran IPA Fisika . Kenyataan ini adalah suatu persepsi negatif terhadap IPA Fisika.Salah satu cara untuk meningkatkan prestasi belajar siswa dalam pembelajaran IPA Fisika adalah melalui pendekatan belajar tuntas (masterylearning).Oleh karena itu penulis perlu melakukan penelitian tindakan kelas dengan judul Peningkatan Prestasi Belajar IPA Fisika dengan Menerapkan Pembelajaran Tuntas(Mastery Learning ) Kelas XI-TKJ SMK Negeri 1 Narmada Kab. Lombok Barat Tahun Pelajaran 2019-2020.
\end{abstract}

Kata Kunci: pembelajaran tuntas; mastery learning; prestasi belajar.

\begin{abstract}
Learning achievement is the result or result of learning activities. To know about learning achievement, it is necessary to explain about the nature of learning. Learning is a process carried out by a person to obtain a new behavior change as a whole, as a result of experience (Slameto, 1991). Where the changes are continuous and functional, occur consciously, are positive and active, not temporary, purposeful or directed, and cover all aspects of behavior, hereinafter referred to as learning achievement. Learning achievement can be said to be imprinted or constant, if the changes that occur as a result of the learning process are durable and not simply erased. The learning process, especially Physics Science, will be more effective and meaningful if students participate actively, by not showing a passive attitude in the classroom or outside the classroom. But until now, there are still many complaints that Physics Science subjects are boring, uninteresting, confusing which tends to make students less responsive during lessons, there are even students who don't go to school because there are Physics Science subjects. This fact is a negative perception of Science Physics. One way to improve student achievement in learning science physics is through a mastery learning approach. Therefore, the authors need to conduct classroom action research with the title Improving Physics Science Learning Achievement by Applying Mastery Learning for Class XI-TKJ SMK Negeri 1 Narmada Academic2019-2020 Year.
\end{abstract}

Keywords: complete learning; mastery learning; learning achievement.

\section{PENDAHULUAN}

IPA Fisika merupakan salah satu mata pelajaran yangdiajarkan pada semua jenjang. IPA Fisika merupakan sarana berpikir ilmiah untuk menujuperkembangan ilmu pengetahuan dan teknologi, iniberarti bahwa IPA Fisika merupakan dasar dari ilmu lain. Tetapi adasebagian siswa yang masih beranggapan 
bahwa IPA Fisika merupakanpelajaran yang menakutkan dan mata pelajaran yang sulit, sehinggamereka tidak berminat dan cenderung tidak merespon.

Keberhasilan pembelajaran dapat dilihat dari prestasi belajar siswa dan pemahaman serta penguasaan materi yang diberikan. Makin tinggi tingkat pemahaman dan penguasaan materi, maka makin tinggi pula tingkat keberhasilan pembelajaran. Keberhasilan pembelajaran IPA Fisika dapat diukur melalui tingkat kemampuan siswa dalam memahami dan menerapkan berbagai konsep untuk memecahkan masalah dan padaakhirnya mampu mencapai prestasi yang baik. Prestasi belajar antara siswayang satu dengan yang lain berbeda-beda.

Berdasarkan observasi di kelas kelemahan belajar IPA Fisika di kelas XI-TKJ SMK Negeri 1 Narmada adalah (1) siswa tidak mampu menguasai hubungan antar konsep, (2) siswa kurang memperhatikan materi yang diberikan guru, (3) siswa kurang dalam mengerjakan latihan-latihan soal, (4) siswa malu/takut bertanya tentang materi yang belum dimengerti.

Salah satu cara untuk meningkatkan prestasi belajar siswa dalam pembelajaran IPA Fisika adalah melalui pendekatan belajar tuntas (masterylearning). Untuk dapat melaksanakan pembelajaran IPA Fisika dengan pendekatan belajar tuntas maka diperlukan adanya kerja sama antara guru IPA Fisika dengan peneliti yaitu melalui penelitian tindakan kelas (PTK). Proses PTK ini memberikan kesempatan kepada peneliti, guru IPA Fisika untuk mengidentifikasi masalahmasalah pembelajaran di sekolah sehingga dapat dikaji, ditingkatkan dan dituntaskan. Dengan demikian proses pembelajaran IPA Fisika di sekolah yang menerapkanpendekatan belajar tuntas, diharapkan dapat meningkatkan prestasi belajarIPA Fisika siswa.

\section{METODE PENELITIAN \\ Subjek Penelitian}

Penelitian ini merupakan penelitian tindakan kelas, yang dilakukan secara bertahap-tahap sampai mendapatkan hasil yang diinginkan. Jumlah siswa kelas XI-TKJ secara keseluruhan yaitu 35 orang.

\section{Setting Penelitian}

1. PTK dilakukan di SMK Negeri 1 Narmada Tahun Pelajaran 2019-2020.

2. Kelas XI di SMK Negeri 1 Narmadaterdiri dari 6kelas dan jumlah siswa tiap kelas relatif cukup besar dibandingkan dengan sekolah lainnya di wilayah Kabupaten Lombok Barat.
3. PTK dilakukan pada siswa kelas XI-TKJ dengan jumlah 35 orang ( $P=19$ orang dan $L=16$ orang ).

\section{Rancangan Penelitian}

1. Tindakan dilaksanakan dalam 3 siklus

2. Kegiatan dilaksanakan dalam semester ganjil tahun pelajaran 2019-2020.

3. Lama penelitian 6 pekan efektif dilaksanakan mulai tanggal 12 September 2019 sampai dengan 17 Oktober 2019.

\section{Variabel Penelitian}

Dalam penelitian tindakan kelas ini variabel yang diteliti adalah peningkatan prestasi belajarIPA Fisika melalui model pembelajaran tuntas (Mastery learning) kelas XI-TKJ SMK Negeri 1 NarmadaKabupaten Lombok Barat.

Variabel tersebut dapat dituliskan kembali sebagai berikut :

$\begin{array}{lll}\text { Variabel } & \text { Peningkatan Prestasi } \\ \text { Harapan } & \text { belajar siswa } \\ \text { pelajaran IPA Fisika } & \text { kelas XI.TKJ } \\ \text { Variabel } & \begin{array}{l}\text { Penerapan model } \\ \text { pembelajaran Tuntas }\end{array} \\ \text { Tindakan : } & \text { (Mastery Learning). }\end{array}$

Adapun indikator yang diteliti dalam variabel harapan terdiri dari:

1. Kemampuan meningkatkan prestasi siswa pelajaran IPA Fisika .

2. Kemampuan siswa dalam pembelajaranIPA Fisika melalui Penerapan belajar tuntas (mastery learning)

3. Keefektifan pembelajaran IPA Fisika melalui penerapan model belajar tuntas (mastery learning)

Sedangkan variabel tindakan memiliki indikator sebagai berikut :

1. Tingkat kualitas perencanaan

2. Kualitas perangkat observasi

3. Kualitas operasional tindakan

4. Kesesuaian perencanaan dengan tindakan kelas

5. Kesesuaian teknik yang digunakan meningkatkan prestasi siswa pelajaran IPA Fisika .

6. Tingkat efektifitas pelaksanaan pembelajaran dengan penerapan belajar tuntas (mastery learning)

7. Kemampuan siswa dan guru dalam penerapan model belajar tuntas (mastery learning)

Teknik Analisis Data

Dalam analisis data teknik yang digunakan adalah ; 


\section{Kuantitatif}

Analisis ini digunakan untuk menghitung besarnya peningkatan prestasi belajar siswa pelajaran IPA Fisika melalui penerapan model belajar tuntas ( mastery learning), menggunakan prosentase ( $\%)$.

\section{Kualitatif}

Teknik analisis ini digunakan untuk memberikan gambaran hasil penelitian secara ; reduksi data, sajian deskriptif, dan penarikan simpulan.

\section{HASIL DAN PEMBAHASAN}

\section{Pelaksanaan Tindakan dan Pengamatan}

Setelah dilakukan tindakan pada siklus 1 , siklus 2 dan siklus 3 menunjukkan hasil pada Tabel 1.

Tabel 1. Analisis Hasil Tes Pelajaran IPA Fisika dalam Meningkatkan Prestasi belajar siswa dengan menerapkan Pembelajaran Tuntas ( Mastery Learning )

\begin{tabular}{lccc} 
& $\begin{array}{l}\text { Skor } \\
\text { sebelum }\end{array}$ & $\begin{array}{c}\text { Skor } \\
\text { setelah }\end{array}$ & $\begin{array}{c}\text { Skor } \\
\text { setelah }\end{array}$ \\
\cline { 2 - 4 } & Tindakan & $\begin{array}{c}\text { Tindakan } \\
1\end{array}$ & $\begin{array}{c}\text { Tindakan } \\
2\end{array}$ \\
\cline { 2 - 4 } & Siklus 1 & Siklus 2 & Siklus 3 \\
\hline $\begin{array}{l}\text { Jumlah skor } \\
\begin{array}{l}\text { Skor Maksimum } \\
\text { Individu }\end{array}\end{array}$ & 1415 & 2306 & 2659 \\
$\begin{array}{l}\text { Skor Maksimum } \\
\text { Kelas } \\
\text { Jumlah siswa } \\
\text { yang tuntas }\end{array}$ & 100 & 100 & 100 \\
$\begin{array}{l}\text { Jml siswa yg } \\
\text { blum tuntas }\end{array}$ & 11 & 3500 & 3500 \\
$\begin{array}{l}\text { Nilai rata-rata } \\
\text { Ketuntasan }\end{array}$ & 24 & 26 & 34 \\
klasikal & 40,43 & 65,89 & 75,97 \\
\hline
\end{tabular}

\section{Analisis Data Deskriptif Kuantitatif}

1. Pencapaian Prestasi belajar siswa kelas XITKJ sebelum diberi tindakan

$$
=\frac{1415}{3500} \times 100=40,43
$$

2. Pencapaian prestasi siswa kelas XI-TKJ setelah diberi tindakan pengelompokan siswa berdasarkan nomor panggilan (acak berdasarkan tempat duduk )

$$
=\frac{2306}{3500} \times 100=65,89
$$

3. Pencapaian prestasi siswa kelas XI-TKJ setelah diberi tindakan pengelompokan siswa berdasarkan kemampuan akademik

$$
=\frac{2659}{3500} \times 100=75,97
$$

Dari hasil analisis tersebut dapat

disimpulkan bahwa

1. Terjadi peningkatan prestasi setelah diberi tindakan yaitu 40,43 menjadi 65,89 ada kenaikan sebesar $=25,46$
2. Dari sebelum tindakan ( siklus 1 ) dan setelah tindakan sampai dengan ( siklus 3 ) 40,43 menjadi 65,89, dan dari ( siklus 2 ) ke ( siklus 3) juga ada peningkatan sebanyak 75,97 - 65,89= 10,08 .

3. Rata - rata siswa sebelum diberi tindakan dari 40,43 menjadi 97,22 .

4. Dari tindakan siklus 2 dan setelah tindakan( siklus 3 ) 65,89 menjadi 75,97 berarti ada peningkatan prestasi sebanyak 75,97 - 65,89 = 10,08

Berdasarkan hasil penelitian di atas, maka prestasi belajar siswa dengan menerapkan pembelajaran Tuntas (Mastery Learning )hasilnya sangat baik. Hal itu tampak pada pertemuan dari 35 orang siswa yang hadir pada saat penelitian ini dilakukan nilai rata rata mencapai ; 40,43 meningkat menjadi 65,89 dan pada siklus 3 meningkat menjadi 75,97. Dari analisis data di atas bahwa penerapan pembelajaran Tuntas (Mastery Learning ) dalam kegiatan belajar mengajar lebih berhasil dan dapat meningkatkan motivasi belajar siswa khususnya pada siswa kelas XI-TKJ di SMK Negeri 1 Narmada, oleh karena itu diharapkan kepada para guru dapat melaksanakan model Pembelajaran Tuntas ( Mastery Learning ).Berdasarkan Kurikulum Tingkat Satuan Pendidikan ( KTSP) siswa dikatakan tuntas apabila siswa telah mencapai nilai standar ideal 75 mencapai $\geq 85 \%$. Sedangkan pada penilitian ini, pencapai nilai $\geq 75$ pada ( siklus 3 ) mencapai melebihi target yang ditetapkan dalam KTSP yaitu mencapai $97,22 \%$. Dengan demikian maka hipotesis yang diajukan dapat diterima.

\section{SIMPULAN DAN SARAN}

Dari hasil kegiatan pembelajaran yang telah dilakukan selama tiga siklus, dan berdasarkan seluruh pembahasan serta analisis yang telah dilakukan dapat disimpulkan sebagai berikut: 1) Pembelajaran dengan menerapkan pembelajaran Tuntas (Mastery Learning) dapat meningkatkan prestasi belajarIPA Fisika siswa kelas XI-TKJ di SMK Negeri 1 Narmada yang ditandai dengan peningkatan prestasi belajar siswa dalam setiap siklus, yaitu; 40,43 ; 65,89 ; 75,97; 2) Penerapan Pembelajaran Tuntas ( Mastery Learning ) pada pelajaran IPA Fisika mempunyai pengaruh positif, yaitu dapat meningkatkan motivasi belajar siswa; dan 3) Penerapan model pembelajaran tuntas (mastery learning) dapat meningkatkan kembali materi ajar yang telah diterima siswa selama ini, sehingga mereka merasa siap untuk menghadapi pelajaran berikutnya. 
Dari hasil penelitian yang diperoleh dari uraian sebelumnya agar proses belajar mengajar lebih efektif dan lebih memberikan hasil yang optimal bagi siswa, maka disampaikan saran sebagai berikut: 1) Untuk melaksanakan pembelajaran memerlukan persiapan yang cukup matang, sehingga guru harus mampu menentukan atau memilih topik yang benar-benar bisa diterapkan dengan model pembelajaran tuntas ( mastery learning) agar diperoleh hasil yang optimal; 2) Dalam rangka meningkatkan prestasi belajar siswa, guru hendaknya lebih sering melatih siswa dengan kegiatan penemuan, walau dalam taraf yang sederhana, dimana siswa nantinya dapat menemukan pengetahuan baru, memperoleh konsep dan keterampilan, sehingga siswa berhasil atau mampu memecahkan masalahmasalah yang dihadapinya; dan 3) Perlu adanya penelitian yang lebih lanjut, karena hasil penelitian ini hanya dilakukan di SMK Negeri 1 Narmada tahun pelajaran 2019-2020.

\section{UCAPAN TERIMAKASIH}

Terima kasih penulis sampaikan kepada Kepala Sekolah SMKN 1 Narmada yang telah mendukung kegiatan penelitian ini sehingga bisa selesai tepat pada waktunya.

\section{DAFTAR RUJUKAN}

Astuti, Fitri. (2007). Usaha Meningkatkan Keaktifan Siswa dalam Merespon Pelajaran IPA Fisika Melalui Pendekatan Belajar Tuntas. SkripsiUMS (tidak diterbitkan).

Arikunto, Suharsimi. (2002). Prosedur Penelitian Suatu Pendekaran Praktek. Jakarta: Rineka Cipta.

Anonim, 2008. Penelitian Tindakan Kelas. Jakarta: Bumi Aksara

Budiyanti, Ana Rahmi. (2007). Peningkatan Motivasi Belajar Siswa Melalui Pendekatan Belajar Tuntas. SkripsiUMS (tidak diterbitkan).

Djamarah, Syaiful Bahri. (2002). Psikologi Belajar. Jakarta : Rineka Cipta

Hamalik, Oemar. (2001). Proses Belajar Mengajar. Jakarta: Bumi Aksara.

Margono. (2004). Metodologi Penelitian Pendidikan. Jakarta : Rineka Cipta

Maryamah, Siti. (2007). Usaha Meningkatkan Pemahaman Konsep, Fakta, Prinsip, dan Skill IPA Fisika Melalui Metode Mastery Learning. Skripsi-UMS (tidak diterbitkan).

Moleong. (1990). Metodologi Penelitian. Bandung: Remaja Rosdakarya

Mudjiono, Dimyati. (1999). Belajar dan Pembelajaran. Jakarta : Rineka Cipta
Suradi. 2006. Upaya Peningkatan Minat Belajar IPA Fisika Melalui MetodeBelajar Tuntas (Mastery learning). Skripsi-UMS (tidak diterbitkan).

Suryosubroto. (2002). Proses Belajar Mengajar Di Sekolah. Jakarta : Rineka Cipta.

Sutama. (2000). Peningkatan Efektivitas Pembelajaran IPA Fisika MelaluiPembenahan Gaya Belajar Guru di SLTA Negeri 18 Surakarta. Tesis Magister PPS. UNY (tidak diterbitkan).

TIM. (2001). Pedoman Penulisan Skripsi. Surakarta: UMS.

Wiriaatmadja, Rochiati. (2006). Metode Penelitian Tindakan Kelas. Bandung : Remaja Rosdakarya. 